ACTA THERIOLOGICA

Vol. 25, 8: 81-97, 1980

\title{
Rodent Ecology in Sugarcane in Lower Sind, Pakistan
}

\author{
A. C. SMIET, G. W. FULK \& S. B. LATHIYA
}

Smiet A. C., Fulk G. W. \& Lathiya S. B., 1980: Rodent ecology in sugarcane in Lower Sind, Pakistan. Acta theriol. 25, 8: 81-97 [With 6 Tables \& 4 Figs.].

Rodents were trapped from sugarcane fields bimonthly for 16 months and data on seasonal variation in abundance, diet and reproduction were gathered. Millardia meltada was the most abundant species and maintained year around resident populations in cane fields. Changes in Millardia abundance corresponded to changes in reproductive activity, except in September when abundance was too low, presumably due to emigration to the ripening rice fields, and in November when abundance was too high, presumably due to immigration from harvested rice fields. About half the diet of Millardia was sugarcane in November, December and January, but otherwise little cane was eaten. Mice populations (Mus sp.) resembled Millardia as to seasonal changes in abundance and reproduction, but differed as to diet: mice ate less cane and more insects. Bandicota bengalensis ate cane more frequently than Millardia did, i.e., $50 \%$ or more of its total diet for half of the year, but was less abundant and accounted for only $24 \%$ of the crop damage. Bandicota populations in cane were the most transitory; and changes in abundance seemed to be independent of reproduction. Nesokia indica probably maintained stable resident populations, but this fossorial rodent was inadequately sampled. These observations are compared with a similar study in Sind rice fields and the difference in utilization of these crops by rodents is discussed. It is suggested that sugarcane serves as a source of rodent infestation to other crops.

[Vertebrate Pest Centrol Centre, P. O. Box 8401, Univ. Campus, Karachi 32, Pakistan].

\section{INTRODUCTION}

Sugarcane has a long growing season and is especially vulnerable to rodent attack. Rodents damage cane wherever it is grown and, in some parts of the world, this problem has been studied: Hawaii ( $\mathrm{K}$ a m i, 1966; Hood et al., 1971), Jamaica (M e tcalf e \& $\mathrm{Thomas}, 1966$ ), Mexico (Collado \& R u a no, 1962) and India (B indra \& S a gar, 1977). In most of these countries the rodent pests are species of Rattus. In Pakistan and India, however, the sugarcane rodent community is complex, including representatives of at least 4 genera: Bandicota, Millardia, Nesokia and Tatera. Although this rodent community has been observed and studied in other agricultural habitats (B in d r a \& S a g a r, 1977; F ulk, L a thi y a \& K hok har, 1979), it, nevertheless, [81] 
remains poorly understood compared to other groups of rodent pests.

Agriculture in Pakistan is labor intensive and cropping is usually mixed. Sugarcane fields are small and adjacent to other crops. In contrast, cane production in many other countries is highly mechanized and done in large monocultures.

Herein we report on a 16-month study of the ecology of rodent pests to sugarcane in lower Sind, Pakistan. We have used methods which enabled us to suggest a general picture of the ecology of these pests and to compare results with our earlier study in the same area $(\mathrm{F} \mathrm{ulk}$ et al., 1979a).

\section{STUDY AREA}

Rodent population were sampled in the vicinity of the Khoski Sugar Mill, Badin District $\left(24^{\circ} 41^{\prime} \mathrm{N}-69^{\circ} 08^{\prime} \mathrm{E}\right)$, situated near the Indus Delta about $250 \mathrm{~km}$ east of Karachi.

The main crop in Badin District is rice grown in large tracts from June to October. However, sugarcane is the predominant crop $(20,000 \mathrm{ha})$ in the area near the mill, where rice is of secondary importance. Wheat is grown from November

Table 1

Mean temperature and rainfall data at Badin Weather Station based on 30 years (1947 through 1976).

\begin{tabular}{lccc}
\hline $\begin{array}{l}\text { Month } \\
\text { Temperature, }{ }^{\circ} \mathrm{C}\end{array}$ & $\begin{array}{c}\text { Mean Minimum } \\
\text { Temperature, }{ }^{\circ} \mathrm{C}\end{array}$ & $\begin{array}{c}\text { Mean } \\
\text { Rainfall, mm }\end{array}$ \\
\hline January & 25,5 & 7.9 & 1.14 \\
February & 27.7 & 10.3 & 1.90 \\
March & 35.3 & 15.9 & 4.01 \\
April & 39.3 & 20.0 & 2.57 \\
May & 39.5 & 21.4 & 0.00 \\
June & 35.9 & 23.0 & 5.76 \\
July & 36.0 & 24.0 & 72.29 \\
August & 34.2 & 20.8 & 50.70 \\
September & 34.9 & 22.0 & 54.70 \\
October & 34.2 & 20.3 & 4.24 \\
November & 32.9 & 14.2 & 0.00 \\
December & 26.7 & 9.5 & 0.53 \\
Total & & & 197.84 \\
\hline
\end{tabular}

till March in few small fields scattered between the sugarcane fields. About half of the sugarcane crop is from seed, while the other half is a "ratoon " crop (resprouting of the first crop). The average yield for the Khoski area in 19771978 was estimated to be 23 tons per hectare, which was about half the mean productivity for all of Pakistan and about one-sixth that achieved by major sugarcane producing countries, such as Cuba and Brazil.

Typically, the sugarcane harvest starts in November and continues until April. The harvested fields (about 0.25 ha in size) are prepared either for another sugarcane crop, for a wheat crop, or left fallow and planted with rice in June. 
The young cane will be harvested the next winter and hence the crop cycle is 10-12 months.

Salinity is one of the major problems in this area, and salty patches of uncultivated land occur between cane fields. Swamps, situated in dead river arms, are another common feature of the landscape. Common plants, both in cultivated and uncultivated land are Tamarix sp., Cyperus glomeralis, Desmostachya bipinnata, Paspalidium geminatum, Chenopodium album, Scirpus maritimus and Brassica campestris.

Weather data for Badin town. $35 \mathrm{~km}$ west of Khoski, are shown in Table 1 . The years of 1976 and 1977 were atypical; only 7 out of the last 30 years had more rainfall.

\section{METHODS}

Starting in November, 1976, snap-trapping was carried out bimonthly through March, 1978. Two snap traps were set every 10 meters in a line of 50 traps along the edge of sugarcane fields, about $1-2$ meters into the crop. Before July, 1977, two farms were visited and different fields in these farms were sampled. From July, 1977, and onwards three farms were visited on each trip, two being the same as before and the third different each time. Precautions were taken so that individual fields were not sampled more than once. One trip was made every two months until July, 1977. Thereafter, two trips were made every two months: a major one on a bimonthly basis and one usually 3 weeks after the major one. This sampling schedule was also part of a rodent control scheme that will be reported elsewhere. To represent a bimonthly sample, data from the two trips were combined.

The percent trap success of the sampling programme described above was used as the measure of rodent abundance. However, data on reproduction and diet also included animals from two additional sources: trapping in fields baited with rodenticide and trapping by an animal hunter in December, 1976.

Animals were autopsied; sex, weight and length were recorded. Females were categorized as lactating, with perforate or imperforate vagina, estrus, parus (embryos and/or placental scars) or nulliparus. The visibility of the tubules in the cauda epidymys was recorded for males.

An index of the production of young $(P)$ was calculated for each bimonthly sample for each species according to the formula:

$$
P=(\% \text { trap success } \times \% \text { pregnant } \times \text { litter size }): 100
$$

Lower jaws from the larger species were collected, cleaned in the laboratory and the height of the first molar was measured on the median side from the bottom of the first groove to the crown.

Stomachs were preserved in the field in $10 \%$ formalin and their contents examined in the laboratory following the procedure in $\mathrm{Fulk}$ et al. (1979a). A crop damage index was calculated for each species for each month. This index was based on the abundance of the pest species and on the proportion of sugarcane in the diet as in Fulk et al. (1979a).

The number of young per female per year produced by the population was calculated for each species from the pregnancy rate, according to South wick (1966). In addition, the average number of young produced by each female collected 
was estimated by the procedure in $\mathrm{Fulk}$ et al. (1979a), which considers counts of placental scars and embryos. The average age $(A A)$ of adult females collected was then estimated by

$$
A A \text { in months }=\frac{\text { number of young per female collected }}{\text { number of young per female per year }} \times 12+X
$$

Where $X$ is the age in months to reach sexual maturity, taken to be 2.5 for Bandicota, 2 for Millardia and 1 for Mus. Only data from February, 1977, through January, 1978, were used in these calculations.

Differences in frequencies were tested in a $2 \times 2$ table using the G-statistic (S o k a l \& R o h lf, 1969, p. 591).

We have not assigned a species name to the mice, since little is known about the systematics of Mus in this area. All the animals we refer to as Mus sp. seemed to be morphologically identical to Mus musculus.

Voucher specimens of Mus as well as of the other small mammal species collected are housed at the British Museum for Natural History (London) and in the Vertebrate Pest Control Centre (Karachi).

\section{RESULTS}

Over the whole study period, an effort of 4291 trapnights was expended and 979 animals were examined.

$$
\text { Millardia meltada (Gra y, 1837) }
$$

A total of 570 Millardia was examined. Data on abundance, reproduction and diet are summarized in Fig. 1. Abundance was relatively stable

Table 2

Seasonal variation in pregnancy rates; number of adult females examined shown

\begin{tabular}{|c|c|c|c|c|c|}
\hline & Millardia & Bandicota & Tatera & Mus & Nesokia \\
\hline November 1976 & 0 (11) & - & - & - & - \\
\hline December 1976 & 0 (48) & 0 (17) & 0 (14) & - & 0 (3) \\
\hline February 1977 & $40(25)$ & 66.7 & $25 \quad(4)$ & $50 \quad(4)$ & - \\
\hline May 1977 & $52.4(21)$ & - & - & 40 (10) & 0 (1) \\
\hline July 1977 & $45.7(35)$ & $12.5 \quad(8)$ & 0 (1) & 46.7 (15) & 0 (4) \\
\hline September 1977 & $64.7(34)$ & $50 \quad(2)$ & $0 \quad(3)$ & $40 \quad(5)$ & $100(1)$ \\
\hline November 1977 & $8.2(49)$ & 0 & - & 9.1 (11) & $0(2)$ \\
\hline January 1978 & 0 (23) & $50 \quad(2)$ & - & $0 \quad(4)$ & - \\
\hline March 1978 & $64.7(17)$ & $100 \quad(3)$ & $80 \quad$ (5) & $75 \quad$ (4) & - \\
\hline
\end{tabular}
in parentheses.

over most of the year and reached a peak in the winter months (December, 1976; November, 1977). Reproductive activity occurred throughout the year, except in the cool months of December and January, when pregnancy rates were zero (Table 2). 
Generally the abundance depended on the production of young. However, in September abundance was low in spite of a peak in production of young two months earlier and in November abundance increased to $31.8 \%$ in spite of decreasing production of young. Clearly, emigration and immigration, respectively, influenced the abundance in these months.

Seasonal changes in the age structure of the population can be implied
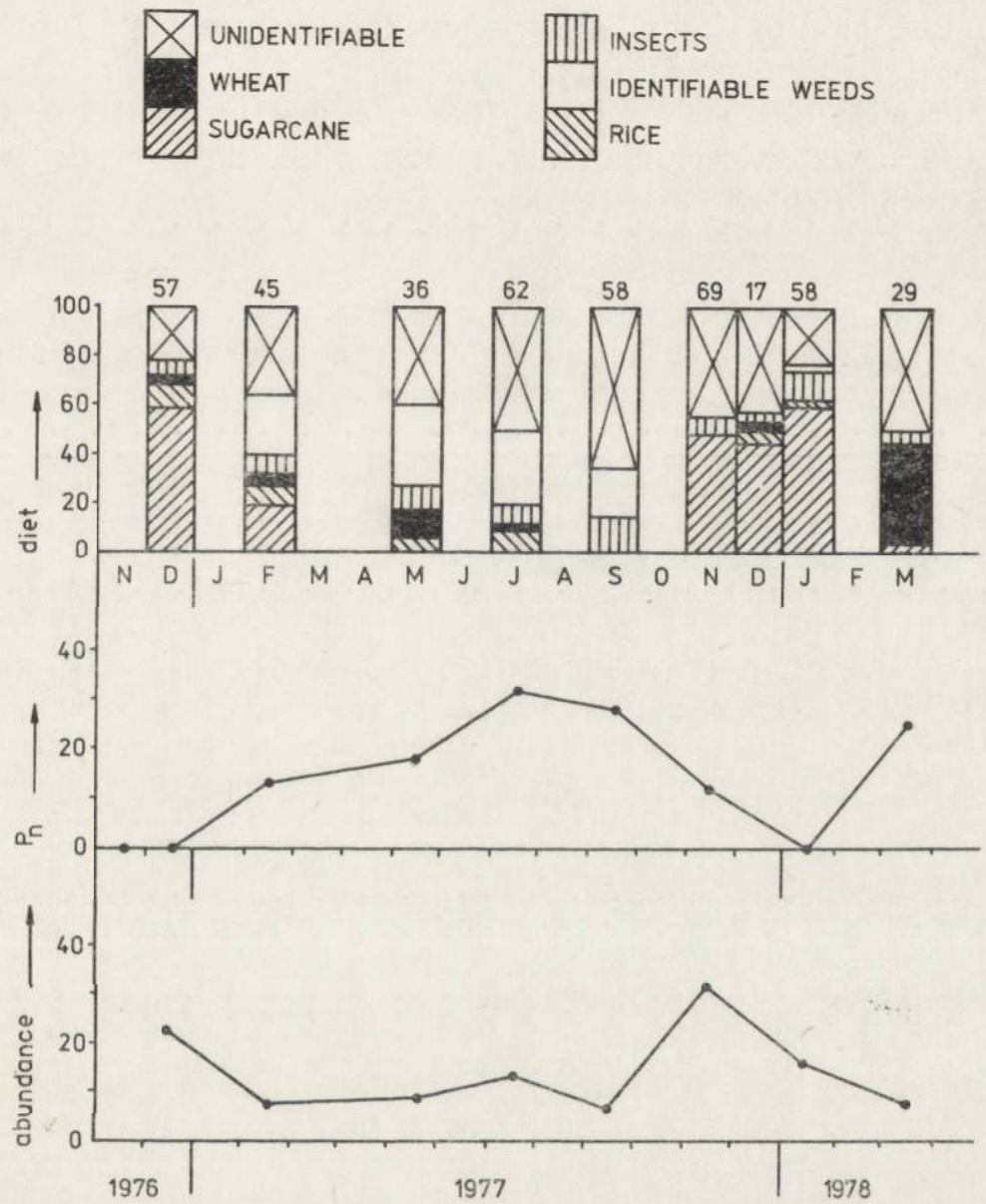

Fig. 1. Abundance, production of young and diet of Millardia meltada; numbers above the bars indicate sample size.

from tooth height data (Table 3). In January and February, following the period of reproductive inactivity, the proportion of old animals (tooth height $\leqslant 2$ ) was high $(42$ and $65 \%$ ) and no young animals were caught (tooth height $\geqslant 7$ ). Otherwise, young animals accounted for 12 to $33 \%$ of each sample and the percentage of old animals never exceeded 25 . 
The diet changed considerably over the year. Sugarcane formed a large $(>49 \%)$ proportion of the diet only in November, December and January. In these months, the cane was sweet. Although the cane was still sweet in February and March, other food seemed to be preferred. In March, $43 \%$ of the diet consisted of wheat. The seeds of Chenopodium album and Paspalidium geminatum accounted for most of the identifiable weeds in the months from February-July. Insects always formed part of the diet, ranging from 5 to $13 \%$.

Very little rice was eaten during the rice season, but traces $(<10 \%)$ of rice and wheat were found in months when these crops were not standing in the field.

Table 3

Age structure: percentages of animals with small or larger tooth height for each sample.

\begin{tabular}{|c|c|c|c|c|c|c|c|c|c|}
\hline Tooth Height & $\begin{array}{l}\text { Dec. } \\
1976\end{array}$ & $\begin{array}{l}\text { Feb. } \\
1977\end{array}$ & $\begin{array}{l}\text { May } \\
1977\end{array}$ & $\begin{array}{l}\text { July } \\
1977\end{array}$ & $\begin{array}{l}\text { Sept. } \\
1977\end{array}$ & $\begin{array}{l}\text { Nov. } \\
1977\end{array}$ & $\begin{array}{l}\text { Jan. } \\
1978\end{array}$ & $\begin{array}{l}\text { Mar. } \\
1978\end{array}$ & Total \\
\hline \multicolumn{10}{|c|}{ Millardia } \\
\hline Sample size & 60 & 34 & 35 & 50 & 46 & 97 & 43 & 30 & 395 \\
\hline $0-2$ & 25 & 65 & 17 & 20 & 15 & 14 & 42 & 3 & 24 \\
\hline $3-4$ & 35 & 32 & 14 & 20 & 35 & 14 & 33 & 44 & 26 \\
\hline $5-6$ & 28 & 3 & 52 & 38 & 20 & 40 & 25 & 20 & 30 \\
\hline$\geqslant 7$ & 12 & 0 & 17 & 22 & 30 & 32 & 0 & 33 & 20 \\
\hline \multicolumn{10}{|c|}{ Bandicota } \\
\hline Sample size & 21 & 1 & - & 15 & 8 & 8 & 3 & 5 & 61 \\
\hline $0-5$ & 14 & 0 & - & 60 & 25 & 25 & 0 & 0 & 26 \\
\hline $6-10$ & 34 & 100 & - & 13 & 13 & 12 & 0 & 0 & 20 \\
\hline $11-15$ & 38 & 0 & - & 27 & 25 & 50 & 33 & 80 & 38 \\
\hline$\geqslant 16$ & 14 & 0 & - & 0 & 37 & 13 & 67 & 20 & 16 \\
\hline \multicolumn{10}{|c|}{ Tatera } \\
\hline Sample size & 6 & 6 & 1 & 2 & 5 & 4 & 1 & 5 & 30 \\
\hline $0-5$ & 17 & 83 & 0 & 50 & 0 & 0 & 100 & 40 & 33 \\
\hline $6-10$ & 33 & 17 & 100 & 0 & 20 & 0 & 0 & 20 & 20 \\
\hline$\geqslant 11$ & 50 & 0 & 0 & 50 & 80 & 100 & 0 & 40 & 47 \\
\hline \multicolumn{10}{|c|}{ Nesokia } \\
\hline Sample size & 1 & - & 2 & 4 & 2 & 7 & 2 & - & 18 \\
\hline $0-5$ & 100 & - & 0 & 50 & 100 & 0 & 0 & - & 28 \\
\hline $6-10$ & 0 & - & 50 & 25 & 0 & 14 & 0 & - & 17 \\
\hline$\geqslant 11$ & 0 & 一 & 50 & 25 & 0 & 86 & 100 & - & 55 \\
\hline
\end{tabular}

The average litter size was 5.1 (S.D. $=1.6 ; n=74)$. An increase in litter size was observed from 4.4 in February $(n=10)$ to 5.9 in September $(n=21)$. The difference between February and September is significant, while the difference between other months is not (Duncan's New Multiple Range Test; $5 \%$ level). There appeared to be no relationship 
between the age of the female, as measured by tooth height, and litter size $(r=0.31 ; \mathrm{n}=47)$.

The reproductive potential of the whole population, as measured by the Southwick procedure, was 39.8 young per female per year (Table 4). The average age of adult females was 2.9 months.

Bandicota bengalensis (G r a y \& $\mathrm{H}$ a r d w i c ke, 1833)

A total of 100 Bandicota was examined. Data on abundance, reproduction and diet are summarized in Fig. 2. Abundance was generally much lower, compared to Millardia, and fluctuated considerably, being zero in one month (May) and reaching a peak two months later (July).

Production of young also fluctuated greatly, but did not correspond to changes in abundance. For example, no Bandicota was caught in

Table 4

Various population parameters for comparison of rodent populations in rice and sugarc ne. $F=$ Incidence of pregnancy, $A A=$ Average age of adult females.

\begin{tabular}{|c|c|c|c|c|c|c|c|}
\hline Crop/Authors & Species & $\begin{array}{c}\text { Percent } \\
\text { Trap } \\
\text { Success }\end{array}$ & $\begin{array}{c}\text { No. Young } \\
\text { per } \\
\text { Female } \\
\text { Collected }\end{array}$ & $\begin{array}{l}\text { No. Young } \\
\text { per } \\
\text { Female } \\
\text { per Year }\end{array}$ & $F$ & $A A$ & $\begin{array}{l}\text { Avg. } \\
\text { Litter } \\
\text { Size }\end{array}$ \\
\hline $\begin{array}{l}\text { Sugarcane } \\
\text { Present } \\
\text { study }\end{array}$ & $\begin{array}{l}\text { Bandicota } \\
\text { Millardia } \\
\text { Mus }\end{array}$ & $\begin{array}{r}1.8 \\
14.5 \\
3.5\end{array}$ & $\begin{array}{l}8.9 \\
3.0 \\
4.2\end{array}$ & $\begin{array}{l}43.6 \\
39.8 \\
43.5\end{array}$ & $\begin{array}{l}6.7 \\
7.7 \\
7.9\end{array}$ & $\begin{array}{l}5.0 \\
2.9 \\
2.2\end{array}$ & $\begin{array}{l}6.5 \\
5.1 \\
5.5\end{array}$ \\
\hline $\begin{array}{l}\text { Rice } \\
\text { Fulk et al., } \\
1979 a\end{array}$ & $\begin{array}{l}\text { Bandicota } \\
\text { Millardia } \\
\text { Mus }\end{array}$ & $\begin{array}{l}2.7 \\
1.1\end{array}$ & $\begin{array}{r}7.0 \\
5.4 \\
-\end{array}$ & $\begin{array}{r}28.2 \\
34.5 \\
-\end{array}$ & $\begin{array}{l}1.6 \\
3.1 \\
-\end{array}$ & $\begin{array}{l}3.9 \\
-\end{array}$ & $\begin{array}{c}10.2^{1} \\
6.7^{2} \\
5.6 \\
5.9\end{array}$ \\
\hline
\end{tabular}

1 Near harvest, 2 Other seasons.

May in spite of the high production of young in February. Bandicota were abundant in July, but most of the animals were old (Table 3; tooth height $\leqslant 5$ ). Apparently, the abundance of Bandicota was always largely determined by immigration and emigration and not by the production of young in the cane fields.

Bandicota seemed to reproduce at a low rate over most of the year. Pregnancy rates were low in the only two months with a reasonable sample size (December and July; Table 2). A few young animals were collected every month except in July (tooth height $\geqslant 16$; Table 3 ).

Sugarcane was eaten in every month. More than $75 \%$ of the diet in November, December and January was cane. The least amounts of cane were consumed in March and July. Wheat was eaten in February and 
March, but rice was never part of the diet. Insects were always eaten, proportions in the diet ranging from 1 to $13 \%$.

Average litter size was $6.5(n=8$; S.D. $=3.7)$. The number of young produced per female per year for the entire population was 43.6 , slightly higher than for Millardia. The average age of adult females was 5 months, higher than Millardia (Table 4).

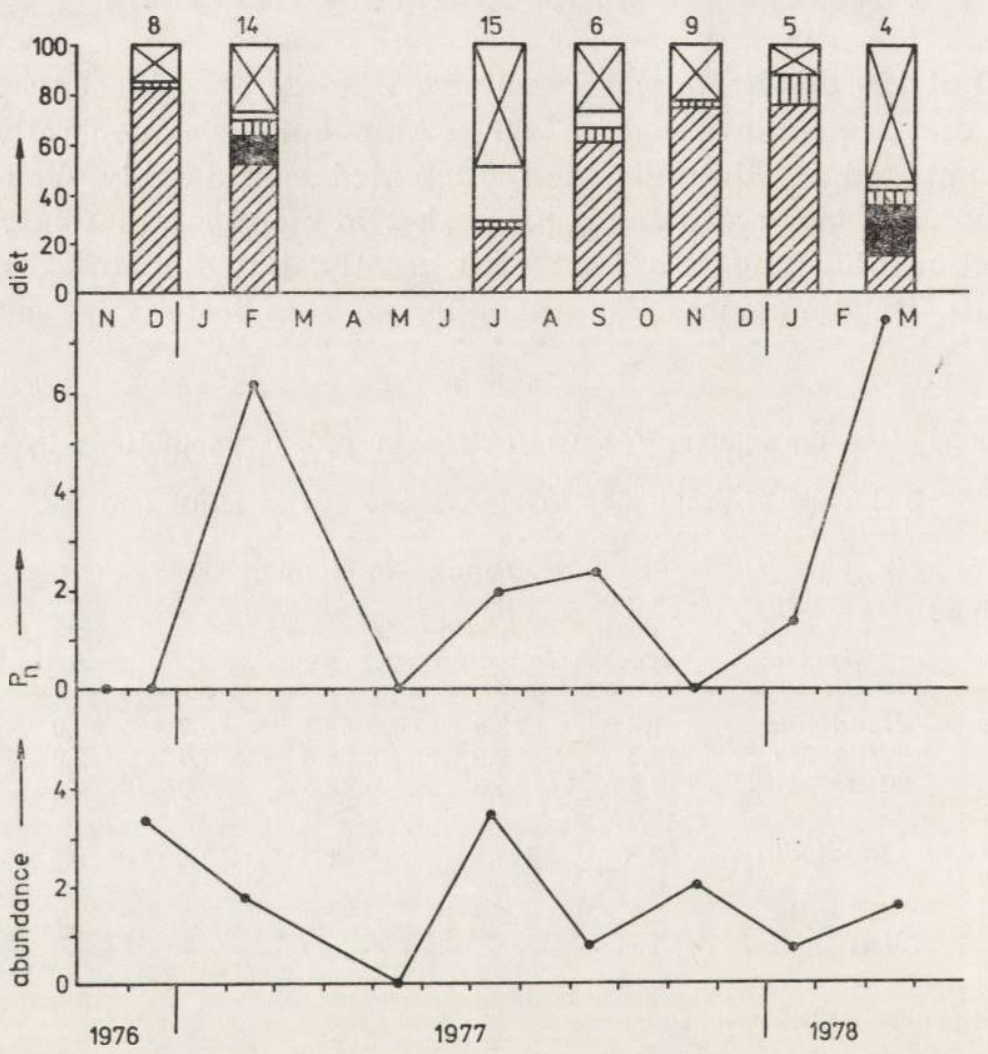

Fig. 2. Abundance, production of young and diet of Bandicota bengalensis; numbers and symbols for diet as in Fig. 1 .

Mus species

A total of 136 mice were examined. Abundance, reproduction and diet are summarized in Figure 3. Abundance was low at the start of the study, increased to a peak in July and declined thereafter. Reproduction showed seasonal changes similar to those for Millardia: a fairly high proportion of females were pregnant in all months except the coldest months, when none or few were pregnant (Table 2).

Generally, abundance depended on the production of young in the preceding months, except in September, when abundance was low in 
spite of peak production of young in the preceding months, and in November, when abundance was high in spite of the previous low reproduction. Apparently, as in the case of Millardia, emigration decreased abundance in September and immigration increased abundance: in November.

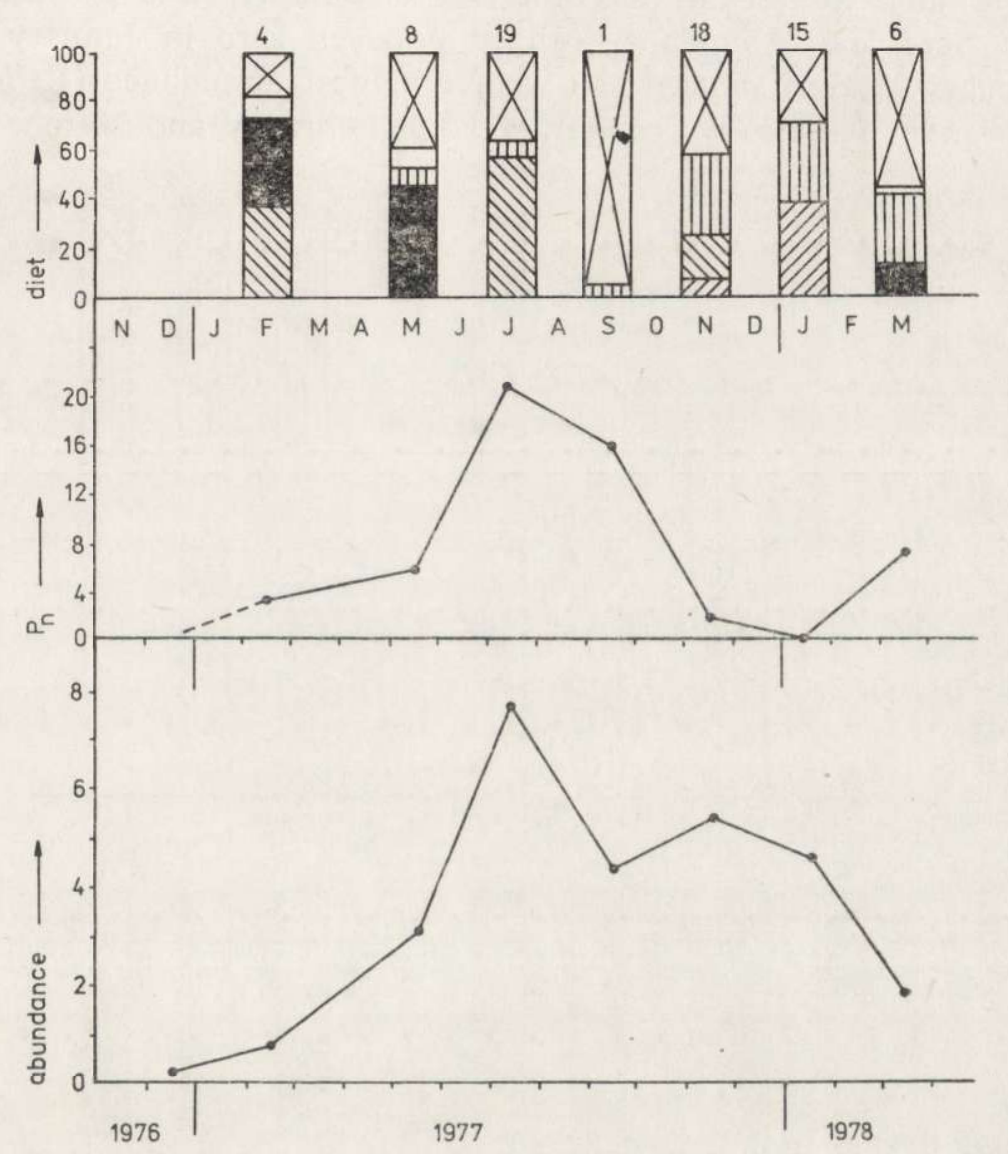

Fig. 3. Abundance, production of young and diet of Mus sp.; numbers and symbols for diet as in Fig. 1.

Significant amounts of sugarcane were only eaten in January $(38 \%)$. Rice was eaten in February, July and November (18-59\%). Wheat was eaten in February, March and especially May $(47 \%)$. Insects were an important part of the diet $(>25 \%)$ in the cooler months of Norember, January and March, but were otherwise eaten in lower amounts. Often a large proportion of the diet could not be identified $(20-94 \%)$.

The litter size averaged $5.5($ S.D. $=2.1 ; n=19)$. The population produced 43.5 young per female per year, more than Millardia and the same as 
Bandicota. The average age for females was 2.2 months, less than the 2.9 months for Millardia and the 5 months for Bandicota (Table 4).

Tatera indica (H a rdwicke, 1807)

A total of 74 animals was examined, of which 40 were brought in by a local animal hunter in December, 1976. Sample sizes for the other months were low. Abundance ranged between zero in January to 1.8 in February. March showed the second highest abundance $(1.4 \%)$. The only pregnant females we caught, were in February and March.

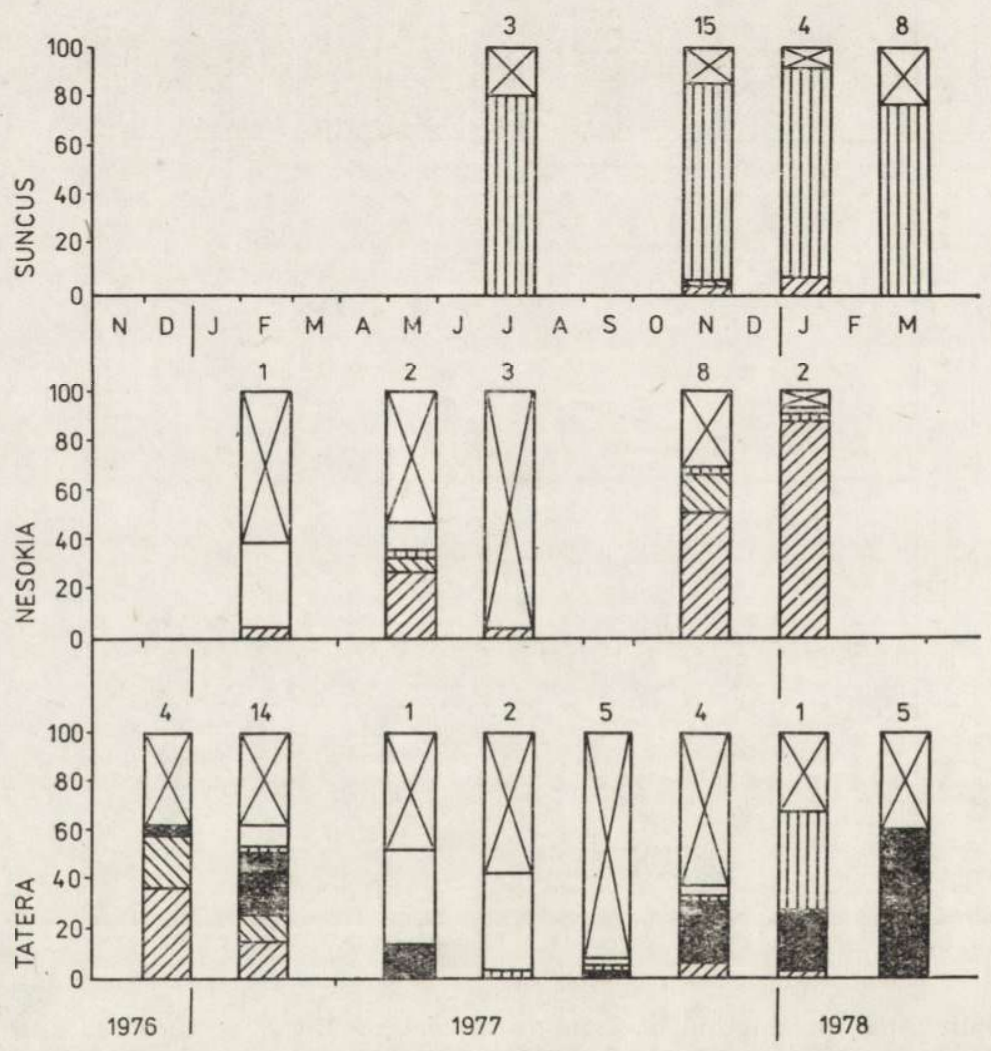

Fig. 4. Diet of Tatera indica, Nesokia indica and Suncus stoliczkanus; numbers and symbols as in Fig. 1.

Litter size averaged $6.6(n=5)$. Toothwear data (Table 3$)$ showed that young animals (tooth height $\geqslant 11$ ) were present throughout the year, except in January and February. To achieve this, breeding must have taken place in all months, except December and January. No breeding in December was confirmed by the lack of pregnant females in the sample of 14 adult females taken in this month (Table 2). 
Tatera seemed to be similar to Mus in diet: both seldom ate cane, but frequently ate cereals or seeds of Chenopodium album. In the case of Tatera, the cereal eaten was mostly wheat. Tatera ate fewer insects than Mus (Fig. 4a).

Nesokia indica (Gra y \& $\mathrm{H}$ a r d w i cke, 1832)

A total of only 31 animals was examined. Nesokia indica, a highly fossorial animal, was not frequently caught in our surface traps. F $\mathrm{ulk}$ et al. (1979a) found that trappability increased when Nesokia fed on rice close to the harvest. Apparently, Nesokia was seldom active on the surface in sugarcane fields; since only a few individuals were caught, in spite of the many burrows observed. The only pregnant female caught, was taken in September and had four embryos (Table 2). Young animals (tooth height $\geqslant 11$ ) were collected in May, July, November and January (Table 3). Together with the pregnant female in September, this suggested that at least some breeding took place during all seasons.

Sugarcane was eaten mostly in November and January (53 and $89 \%$; Fig. 4b). Most of the other food items were unidentifiable fibers, probably from roots. The proportion of insects in the diet was very low $(0-2 \%)$.

Suncus stoliczkanus (Anders on, 1877)

We examined 68 of these small insectivores. Their abundance was lowest in May (trap success $0.4 \%$ ), before the monsoon began, and highest in November $(3.2 \%)$, after the monsoon. Shrew abundance was probably affected by rainfall, presumably indirectly through insect abundance.

Only 4 females were pregnant, 3 in March and 1 in July. Embryo counts were 4, 4, 4 and 5 . Most (50 of 68 ) animals caught were males.

The proportion of insects in the diet was always more than $75 \%$ (Fig. 4c). Traces $(<10 \%)$ of rice and sugarcane were occasionally found.

\section{Rodent Damage to Sugarcane}

Most damage $(87.3 \%$ ) occurred in November, December and January (Table 5). Damage in other months was much lower, ranging between $0.3 \%$ and $6.4 \%$ of the total damage. The large increase in damage between September $(1.6 \%)$ and November $(34.4 \%)$ was due not only to a higher percentage of cane in the rodent diet, but also a higher rodent abundance in November. 
Millardia caused $68.9 \%$ of the damage and Bandicota $24 \%$. A single Bandicota on an average consumed 2.8 times more cane than a single Millardia, but Bandicota was much less abundant and this reduced its contribution to the damage index. Other species contributed about $7 \%$ to the overall damage index.

Table 5

Damage index to sugarcane for each sampling month and each species.

\begin{tabular}{lrrrrrrr}
\hline & Millardia & Bandicota & Tatera & Nesokia & Mus & Total & $\%$ \\
\hline Dec. 1976 & 61.9 & 22.4 & 3.5 & - & - & 87.8 & 32.6 \\
Fe r. 1977 & 6.8 & 8.0 & 2.2 & 0.1 & 0 & 17.1 & 6.4 \\
May 1977 & 0 & - & 0 & 0.7 & 0 & 0.7 & 0.3 \\
July 1977 & 0.1 & 8.3 & 0 & 0.2 & 0 & 8.6 & 3.2 \\
Sept. 1977 & 0 & 4.2 & 0 & 0 & 0 & 4.2 & 1.6 \\
Nov. 1977 & 71.1 & 13.1 & 0.5 & 7.8 & 0.4 & 92.9 & 34.4 \\
Jan. 1978 & 44.9 & 5.9 & 0 & 2.2 & 1.6 & 54.6 & 20.3 \\
March 1978 & 0.7 & 2.6 & 0 & - & 0 & 3.3 & 1.2 \\
Total & 185.5 & 64.5 & 6.2 & 11.0 & 2.0 & 269.2 & - \\
\% & 68.9 & 24.0 & 2.3 & 4.1 & 0.7 & - & 100 \\
\hline
\end{tabular}

\section{Effect of Cane Height}

Trapping was carried out simultaneously in tall cane ( 4 meters high) and in short cane (1-1.5 m high) in February. The tall cane was awaiting harvest, while the short cane had been newly planted in fields harvested in November. Results are summarized in Table 6 .

Table 6

Effect of cane height on rodent abundance; number of animals caught is shown in parentheses.

\begin{tabular}{|c|c|c|}
\hline & \multicolumn{2}{|c|}{ Percent Trap Success } \\
\hline & Short Cane & Tall Cane \\
\hline $\begin{array}{l}\text { Number of trap nights } \\
\text { Millardia }\end{array}$ & $\begin{array}{l}252 \\
7.5^{0} \%(19)\end{array}$ & $\begin{array}{c}370 \\
7.3 \%(27)\end{array}$ \\
\hline Bandicota & $0.4 \%$ (1) & $2.4 \%$ \\
\hline Tatera & $3.2 \% \quad(8)$ & $0.8 \% \quad$ (3) \\
\hline Mus & $2.0 \% \quad(5)$ & $0.3 \% \quad(1)$ \\
\hline Total & $13.1 \%$ & $10.8 \%(40)$ \\
\hline
\end{tabular}

Rodents were slightly more abundant in short cane, but not significantly so $(G=0.74)$. Millardia was equally abundant in short and tall cane $(G=0.02)$. Bandicota, however, was more abundant in tall cane $(G=4.7 ; p<0.05)$ and Tatera and Mus were more abundant in short cane $(G=4.8$ and 4.7 , respectively; $p<0.05)$. 
The Millardia trapped in short cane had diets different from those trapped in tall cane. While samples of 23 stomachs from tall cane contained 671 fragments of sugarcane, samples of the 17 stomachs from short cane contained only 21 fragments $(G=56 ; p<0.005)$. The 9 Bandicota stomachs from tall cane contained $78.2 \%$ sugarcane, while 1 animal trapped in short cane had no cane in its stomach. The stomachs of Tatera and Mus contained very little sugarcane at all.

\section{DISCUSSION}

Our previous study (Fulk et al., 1979a) showed a fundamental difference between the dynamics of Millardia and Bandicota populations in rice fields. Bandicota responded markedly to the sudden abundance of energy-rich food as the rice crop matured. At this time the Bandicota population tripled its pregnancy rate and doubled its litter size. Moreover, Bandicota stored large amounts of rice underground. Millardia, on the other hand, managed to find energy-rich food (insects and seeds) even when the rice crop was not mature. Consequently, Millardia maintained more stable pregnancy rates throughout the year and responded less markedly to the ripening of rice.

Sugarcane differs in two important aspects from rice fields as a rodent habitat. First, sugarcane fields provide cover over a longer period. Second, sugarcane is not an energy-rich food. On the contrary, a study of the digestion of cane by Rattus exulans showed that sugarcane alone is not sufficiently nutritious to keep animals in good condition ( $\mathrm{G}$ a r r is o $\mathrm{n}$ \& Breidenstein, 1970).

The effect of these environmental differences on some parameters of the rodent populations can be seen in Table 4. Bandicota in sugarcane had a litter size about equal to that in rice during the non-harvest months, but much lower than that in rice during the months near harvest. Obviously, maturation of the sugarcane crop did not have the same stimulatory effect on Bandicota reproduction as the maturation of the rice crop did, although cane formed $50 \%$ or more of the diet for 6 months of the year. Bandicota reproduced over most of the year in cane and did not show any sharp peak in pregnancy rate as was the case for the population in rice. Overall, the incidence of pregnancy was higher in the cane population; more young per female per year were produced and the average age was slightly less than in the rice population. The Bandicota population in cane turned over more rapidly than the population in rice. From the data in Table 4, Bandicota appeared to be slightly more abundant in rice. Actually, this is misleading since the abundance in rice fields is based on data collected from 1974-1976, years that 
were more favorable for Bandicota (F u l k et al., 1979b) than 1977-1978 when the abundance in cane was measured. When rice field data from 1977-1978 are compared to sugarcane data from the same years, Bandicota appeared to be slightly more abundant in cane than in rice $(1.8 \%$ trap success in cane vs. $1.1 \%$ in rice).

The corresponding comparison between rice and sugarcane populations for Millardia leads to similar conclusions. Litter size was slightly larger in rice fields, but not significantly so $(p<0.2)$. The incidence of pregnancy for the cane population was much higher; more young per female per year were produced; and the animals in cane were on the average one month younger than in the rice fields. Millardia were more able to find energy-rich food in cane than Bandicota. Millardia ate less cane and had a more varied diet, including insects, weed seeds and cereal seeds. The great stability of the cane habitat and the fact that individuals of Millardia managed to find energy-rich food throughcut the year enabled this species to maintain a much higher abundance in cane than in rice fields.

The above points about Millardia are probably equally true for Mus. The principal difference between the two species was their diet: Mus ate less cane and more energy-rich food than Millardia. The mice were able to find rice and wheat even outside the crop season and ate more insects than Millardia.

Sugarcane formed apparently only a marginal habitat for Tatera, primarily a desert species associated with open terrain $(\mathrm{Prak}$ a sh \& $\mathrm{R}$ a $\mathrm{na}, 1970$ ). In this light it is not surprising that Tatera were more abundant in short cane than in tall cane, where cover is dense. Our evidence that reproduction ceased in the winter is in agreement with B e g \& A j m a l (1977).

Nesokia was inadequately sampled. Our evidence that they can breed the whole year around supports the view of Roberts (1977). The age structure of the Nesokia caught in November and January (Table 3) tends to support our previous conclusion that this species produced more young in the cooler months (F u l k et al., 1979a).

The rodent populations in cane fields were influenced by changes in the surrounding habitats. This was especially true for Bandicota. Millardia and Mus maintained more stable populations in sugarcane. However, in September these species were less abundant than expected on the basis of their reproduction and more abundant than expected in November. We hypothesize that many individuals emigrated to ripening rice fields in September and that they and their offspring immigrated back into the cane after the harvest of rice in November. We made a similar observation while monitoring the recovery of rodent populations after 
the application of rodenticides in cane fields; rodent populations were especially quick to recover in November after the rice harvest.

Movements between cane and wheat were probably of a different type from those between cane and rice. Since wheat fields were small and close to cane fields, normal home range activities of rodents living in cane could easily include foraging in wheat fields. B e g \& $\mathrm{K} \mathrm{h}$ a $\mathrm{n}$ (1977) noted that wheat fields adjacent to sugarcane fields were more damaged by rats than other wheat fields.

Several authors have reported invasion of agricultural fields from the surrounding habitat (T a y lor \& G r e e n, 1976; H o o d et al., 1971;

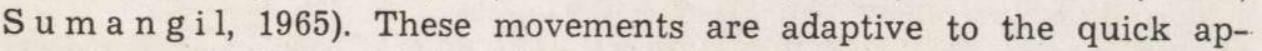
pearance and disappearance of an abundant food supply. We monitored Bandicota movements with radio telemetry equipment and reported long. distance movements up to 640 meters (F ulk et al., 1979a). Even longer movements were suspected. We have also reported that harvest operations in rice fields caused individual Bandicota to move away from their home fields (F u l k et al., 1979d). Movements between sugarcane and cereal crops give rodent populations in cane more importance than indicated by the damage they cause to the cane alone.

Acknowledgements: Thanks are due to the staff of the Vertebrate Pest Control Centre, the Khoski Sugar Mill and the many farmers, who allowed us to trap on their lands. This project was carried out under the auspices of the Food and Agriculture Organization (FAO) of the United Nations and the Agriculturai Research Council of the Pakistan Government.

\section{REFERENCES}

1. Beg M. A. \& A jmal M., 1977: Reproduction in the Indian Gerbil, Tatera indica indica (Hardwicke). Mammalia, 41: 213-221.

2. B e g M. A. \& $\mathrm{K}$ h a n A. A., 1977: Rat damage to the wheat crop. [In: »Abstracts from 18th Annual Conference of Scientific Soc. of Pakistan «]

3. Bindra O. S. \& S a g a r, Prem, 1977: A review of studies on the ecology, biology, damage and control of field rats and field mice in the Punjab. [In: "All India Rodent Seminar ", 1975, Ahmedabad. Eds. Krishnamurty K., Chaturvedi G. C. \& Prakash I.] Rodent Control Project: 82-88, Sidhpur.

4. Colla do J. C. \& Ruano M. A., 1962: The rat problem in the sugarcane plantations of Mexico. Proc. Soc. Sug. Cane Techn. No. 11: 705-711.

5. Fulk G. W., Lathiya S. B. \& Khokhar A. R., 1979 a: Rice field rats of lower Sind: abundance, reproduction and diet. J. Zool., Lond. (in press).

6. Fulk G. W., Akhtar M. T. \& $\mathrm{Khokhar} \mathrm{A.} \mathrm{R.,} \mathrm{1979b:} \mathrm{Annual} \mathrm{variations}$ in rainfall and the abundance of Bandicota bengalensis in Sind rice fields. Mammalia (in press).

7. Fulk G. W., Smiet A. C. \& Khok har A. R., 1979c: Movements of Bandicota bengalensis (Gray 1873) and Tatera indica (Hardwicke 1807) as revealed by radio telemetry. J. Bomb. Nat. Hist. Soc. (in press). 
8. Fulk G. W., Smiet A. C. \& $\mathrm{Khokhar}$ A. R., 1979d: Movement of Bandicota bengalensis and Nesokia indica in rice fields in Sind. J. Bomb. Nat. Hist. Soc. (in press).

9. G a rris on M. V. \& Breidenstein C. P., 1970: Digestion of sugarcane by the Polynesian rat. J. Wildl. Manag., 34: 520-522.

10. Hood G. A., Nas R. D., Lindsa y G. D. \& Hirat a D. N., 1971: Distribution and accumulation of rat damage in Hawaiian sugarcane. J. Wildl. Manage., 35: $613-618$.

11. Ka m i H. T., 1966: Foods of rodents in the Hamakua District, Hawai. Pacific Science, 20: 367-373.

12. Metcalfe J. B. \& $\mathrm{Thom}$ a s G., 1966: Preliminary experiments in Jamaica with a method for determinining loss of sugar resulting from rat damage to sugarcane. Proc. Br W. Ind. Sug. Techn. Asn., 1966: 276-278.

13. Prakash I. \& Rana B. D., 1970: A study of field populations of rodents in the Indian Desert. Z. Angew. Zool., 57: 129-136.

14. Roberts T. J., 1977: The mammals of Pakistan. Ernest Benn Ltd: $1-361$. London.

15. Sokal R. R. \& Rohlf F. J., 1969. Biometry. Freeman and Co.: 1-776. San Francisco.

16. Southwick G. H., 1966: Reproduction, mortality and growth of murid rodent populations. [In: "Indian Rodent Symposium" Calcutta]. The John Hopkins University: 152-176. CMRT and USAID.

17. Sumangil J. P., 1965: Handbook on the ecology of rice field rats and their control by chemical methods. Bureau of Plant Industry, Philippines. 27 p.

18. T a y lor K. D. \& Green M. G., 1976: The influence of rainfall on diet and reproduction in four African rodent species. J. Zool. Lond., 180: 367-389.

Accepted, October 31, 1979.

A. C. SMIET, G. W. FULK i S. B. LATHIYA

\section{EKOLOGIA GRYZONI ZAMIESZKUJACYCH POLA TRZCINY CUKROWEJ W PAKISTANIE}

\section{Streszczenie}

Gryzonie łowiono na polach trzciny cukrowej przez 16 miesięcy, zbierając co 2 miesiące dane odnośnte rozrodu (Tabela 2), zagęszczenia (Tabela 4), struktury wiekowej (Tabela 3) i pokarmu. Millardia meltada była najliczniejszym gatunkiem i populacja jej występowała przez cały rok (Ryc. 1). Zmiany w zagęszczeniu Millardia zgodne były ze zmianami w aktywności rozrodczej, z wyjątkiem września, kiedy to liczebność była niska, przypuszczalnie z powodu migracji na dojrzewające pola ryżowe, i listopada, kiedy liczebność była wysoka, przypuszczalnie z powodu imigracji ze skoszonych pól ryżowych (Tabela 4). W listopadzie, grudniu i styczniu około połowy diety Millardia stanowiła trzcina cukrowa (Ryc. 1), w pozostałych miesiącach trzcina była słabo jedzona. Populacja myszy (Mus sp.) jest podobna do Millardia pod względem sezonowych zmian liczebności i rozrodu, lecz różni 
się pokarmem. Myszy zjadają mniej trzciny a więcej owadów (ryc. 3). Bandicota bengalensis zjada trzcinę częściej niż Millardia (Ryc. 2). W ciągu pół roku stanowiła ona 50 i więcej procent całego pokarmu tego gryzonia. Liczebność Bandicota w trzcinie była bardzo zmienna i niezależna od rozrodu. Nesokia indica prawdopodobnie stale występuje na badanych polach, lecz te gryzonie były bardzo nieliczne w odłowach (Ryc. 4). Obserwacje te porównywano z podobnymi badaniami na polach ryżowych w Sind i różnicami w wykorzystaniu pokarmu. Sugeruje to, że pola trzciny cukrowej mają stałą obsadę różnych gatunków gryzoni, które wychodzą stąd na otaczające tereny rolne. 